\title{
ENERGY VALORIZATION OF WOODY BIOMASS BY TORREFACTION TREATMENT: A BRAZILIAN EXPERIMENTAL STUDY
}

\author{
Clarissa Gusmão Figueirón ${ }^{1, \diamond}$, Benedito Rocha Vital ${ }^{1}$, Angélica de Cássia Oliveira Carneiro ${ }^{1}$, \\ Carlos Miguel Simões da Silva ${ }^{1}$, Mateus Alves Magalhães ${ }^{1}$, Lucas de Freitas Fialho ${ }^{1}$
}

\begin{abstract}
Brazilian productivity of eucalyptus trees is one of the highest in the world, and it has sustainable and viable conditions to supply the demand for woody biomass in a large quantity and diversity. This favorable situation makes Brazil one of the countries with the greatest potential for the production development of torrefied woody biomass on a commercial scale. Torrefaction is a mild pyrolysis applied to increase the energy quality of the feedstock. The aim of this study was to evaluate the Brazilian potential of woody biomass torrefaction for energy purposes. An experimental study was performed evaluating this thermal treatment of eucalyptus wood chips on a semi-continuous screw reactor developed by a Brazilian university. The results showed the increases in the energy quality of eucalyptus wood chips as a function of torrefaction temperature and time. This thermal treatment was technically feasible for the hygroscopicity reduction and the increases of fixed carbon and calorific values of the woody biomass.
\end{abstract}

Keywords: Energy purposes, Eucalyptus wood chips, planted forests, semi-continuous screw reactor, thermal treatment.

\section{INTRODUCTION}

Torrefied biomass is a new "green" fuel source resulting from a mild pyrolysis applied to feedstock on conditions between drying and carbonization processes (Van der Stelt et al. 2011). This thermal treatment consists of a partial degradation of the least energetic fraction from biomass. The main changes caused by torrefaction are the increase in fixed carbon, calorific value, and grindability; as well the reduction in moisture content, hygroscopicity, and heterogeneity (Van der Stelt et al. 2011, Esteves and Pereira, 2009, Medic et al. 2012, Du et al. 2014).

In addition to the material quality, the use of biomass as an energy source depends of another factor, the economic viability. The torrefaction improves the transport logistic of biomass. The torrefied material is easier to handling and presents more amount of energy per volume, when compared with raw material. Thus, the transport costs of treated biomass decrease, which impacts directly in the process viability (Uslu et al. 2008).

Brazil has a high potential for development of the productive chain of torrefied biomass due to the availability of raw material in a large quantity and diversity. This country economy is strongly linked to the primary sectors such as forestry production. The advanced forest improvement program allied with edaphoclimatic conditions and silvicultural techniques provide to Brazilian forestry production a global visibility. The fast growing, high productive and adaptability characteristics allow the Eucalypts to be the main planted specie and presents potential for energetic use (Vital et al. 2013).

In the context of combustible fossil dependence, the use of renewable source of energy is one of main 
target of global policies. The increase of woody biomass participation contributes for the energetic matrix sustainability and diversification of a country. In this sense, a deep knowledge about material quality is one of key points for woody biomass insertion competitively. Through the torrefied biomass characterization, the criteria and parameters of industrial system production are established. So, the detailed information of feedstock could provide an optimization of conversion process of biomass.

The aim of this study was to evaluate the energy valorization of Brazilian woody biomass subjected to dry torrefaction treatment. An experimental study was performed evaluating this thermal treatment of eucalyptus wood chips on a semi-continuous screw reactor developed by a Brazilian university.

\section{Biomass torrefaction for energy purposes}

Torrefied biomass is a solid fuel with intermediate characteristics between the raw biomass and charcoal (Van der Stelt et al. 2011). The degraded part of lignocellulosic sources consists of organic compounds of lower molecular weight, in particular hemicelluloses. This thermal treatment promotes a consequent proportional increase on the contents of others chemical constituents, such as cellulose and lignins (Shen et al. 2010, Da Silva et al. 2016).

Torrefaction causes significant changes to the chemical and physical properties of the lignocellulosic biomass as shown in Figure 1. The degraded part during torrefaction is eliminated as volatile compounds, promoting a consequent concentration of the fixed carbon in the remaining solid fraction. The increase in fixed carbon has a direct correlation with the energy quality of the fuel by raising its calorific value. Partial degradation of the biomass fibrous structure enhances the grindability of this material and reduces the availability of hydrophilic groups for the adsorption of water, making it less hygroscopic (Van der Stelt et al. 2011, Esteves and Pereira, 2009, Medic et al. 2012).
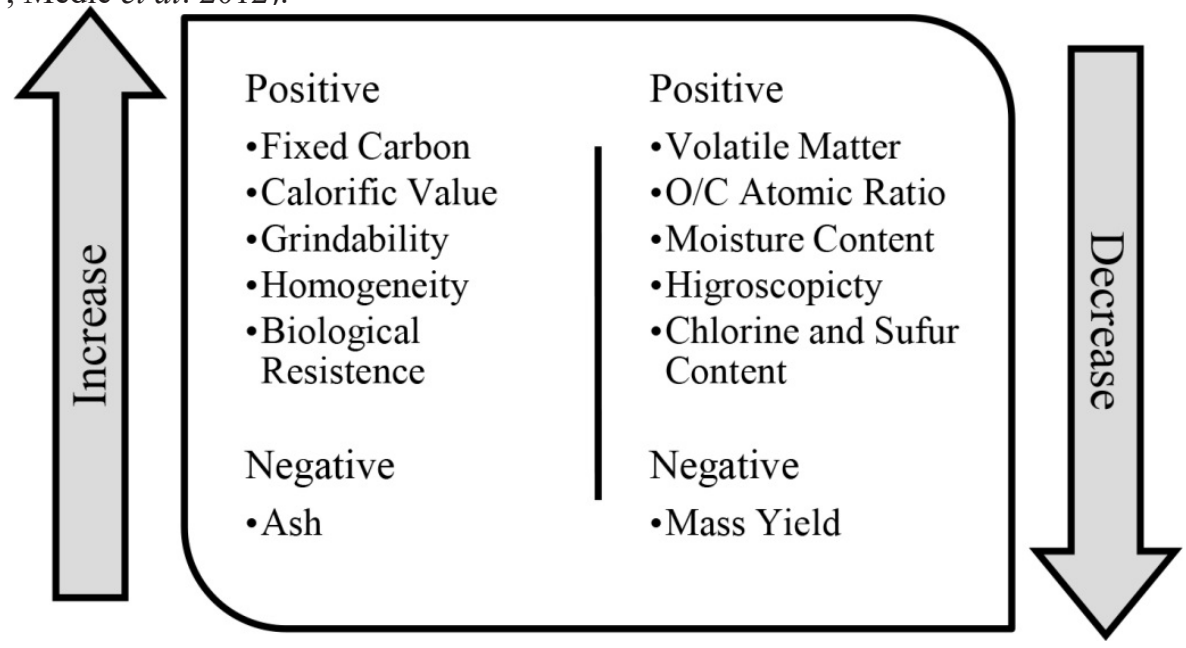

Figure 1: Changes on the physical and chemical properties of lignocellulosic biomass subjected to dry torrefaction for energy purposes (Du et al. 2014, Acharya et al. 2015, Pérez et al. 2015, Bach and Skreiberg 2016, Yue et al. 2017).

Yields and quality of the torrefaction depend on factors inherent to the treatment conditions and to the raw material. The torrefaction can be applied in different conditions to have products with different characteristics. These variations may include the maximum temperature, residence time, heating rate, atmosphere (dry or wet), biomass movement and heat transfer mechanisms. The relevant biomass characteristics may be associated with the chemical composition, moisture content, granulometry, purity, and homogeneity (Esteves and Pereira 2009, Acharya et al. 2015, Bach and Skreiberg 2016, Almeida et al. 2010, Parparita et al. 2014).

Energy valorization of biomass by torrefaction could make it a higher value-added fuel with a greater viability for commercialization. In general, torrefaction promotes a significant increase in efficiency and yields of all stages of processing and conversion of lignocellulosic biomass to energy. These changes justify investment in research and development of torrefaction technologies to efficiently increase the consumption of biomass for primary energy production. 
Technology development is one of the main challenges for torrefied biomass production on an industrial scale. There is not a consolidated base industry that can supply the immediate world demand for the necessary equipment of torrefaction plants. This base includes the entire production line involving the reduction of biomass in chips or particles; drying; torrefaction and cooling. The current torrefaction technologies are adaptations of other systems for thermal treatment or prototype reactors on a small and pilot scale (Koppejan et al. 2012, Wild and Deutmeyer, 2016).

\section{Brazilian production of woody biomass}

Brazil has a high potential for woody biomass production due to its developed sector of planted forest. Brazilian silviculture is recognized due to the highest forest productivity of the world. According to data from IBÁ - Brazilian Tree Industry (IBÁ 2017), the average Brazilian productivity in 2016 for Eucalyptus forests was $35,7 \mathrm{~m}^{3} /$ ha year, while for pine forests it was $30,5 \mathrm{~m}^{3} /$ ha year. The high productivity significantly reduces the time of forest rotation in the country, being up to four times shorter than the rotation reached in countries with a greater tradition in forestry activities, such as Scandinavia and Canada (IBÁ 2017).

Non-native species, such as eucalyptus and pine trees, have ideal growth conditions in many regions of Brazil. Favorable edaphoclimatic conditions are indicated as the primary cause of the high productivity of these species. Brazil has an availability of sunlight, temperature, and rain in relatively adequate and regular quantities (Vital et al. 2013). The historic investments in silvicultural practices and forest management are another important cause to explain this Brazilian productivity. Companies of the Brazilian forestry sector, associated with universities and other research centers, have been achieving significant successes in genetic improvement, fertilization, mechanization, precision forestry and other correlated activities (Stape et al. 2010, Almeida et al. 2010).

The planted forests sector has approximately $78000 \mathrm{~km}^{2}$ that represent less than $1 \%$ of the total Brazilian territory. Planted forests have the environmental function of reducing demand for forest products from native forests. The Brazilian forestry sector destines almost 6 million of hectares for areas of permanent protection, areas of legal reserve, areas of natural heritage reserve, which contributes directly for conservation of biodiversity (IBÁ 2017). Considering the availability of readily arable land, Brazil has possible conditions to expand forest production sustainably further and considering the social and environmental precepts involved.

One of the main sectors that demand the production of woody biomass in Brazil is energy production. Firewood is the second most common biomass that makes up the Brazilian production of primary energy, being surpassed only by sugarcane products. The woody biomass for energy purposes is consumed in the processed condition (fuel, charcoal, pellets, etc.) and not treated. Woody biomasses are lignocellulosic materials directly or indirectly originating from the processing of whole-trees or parts of them. This feedstock includes wood with or without bark, roots, and branches from planted forests, management residuals of native forest or industrial processing residues for the production of charcoal, furniture, pulp and paper, solid wood products, and other derivatives. Table 1 presents a summary of the forest and woody biomass productions during the period from 2012 to 2016 in Brazil.

Table 1: Mean annual production of forest and woody biomass in Brazil between 2012 and 2016.

\begin{tabular}{|l|c|c|c}
\hline \multicolumn{1}{|c|}{ Item } & Gross Values & Unit & Relative Values* \\
\hline \multicolumn{4}{|c}{ Total Area of Planted Trees $(16)$} \\
\hline Eucalyptus & 5,53 & $10^{4} \cdot \mathrm{km}^{2}$ & $72,01 \%$ \\
\hline Pine & 1,58 & $10^{4} \cdot \mathrm{km}^{2}$ & $20,57 \%$ \\
\hline Others & 0,57 & $10^{4} \cdot \mathrm{km}^{2}$ & $7,42 \%$ \\
\hline \multicolumn{4}{|c|}{ Forestry Production $(19)$} \\
\hline Wood fuel & 118,50 & $10^{6} \cdot \mathrm{m}^{3}$ & --- \\
\hline Wood residues & 17,19 & $10^{6} \cdot \mathrm{m}^{3}$ & --- \\
\hline Wood chips and particles & 6,86 & $10^{6} \cdot \mathrm{m}^{3}$ & --- \\
\hline Wood charcoal & 6,49 & $10^{9} \cdot \mathrm{kg}$ & --- \\
\hline Wood pellets & 0,06 & $10^{9} \cdot \mathrm{kg}$ & $9,02 \%$ \\
\hline
\end{tabular}

*Relative to Brazilian Production; toe: tonne of oil equivalent. 
Pine plantations are feedstock, mainly, for panels and lumber production. These areas are concentrated in south states of Brazil (Rio Grande do Sul, Santa Catarina e Paraná). Along of years, these plantations areas remain constant, without perspective of increase. In areas cultivated with pinus in other regions of country, there are a trend of replaced these plantations by Eucalyptus. So, high availability in almost all Brazilian territory, amount of material, productivity and facility of management practices, make the market Brazilian players to prefer Eucalyptus species.

\section{Materials and methods}

In this experimental study, the evaluated material was Eucalyptus urophylla wood from a seven-year-old experimental plantation located in Minas Gerais state, Brazil. The bark-free wood had a specific gravity of 0,45 g.cm ${ }^{-3}$ and a chemical composition of 75,4\%-holoceluloses $21,7 \%$-lignin, $2,8 \%$-extractives, and $0,1 \%$-ash. The material was reduced to small chips with average size of $16,12 \mathrm{~mm}$, and dried at $103 \pm 3^{\circ} \mathrm{C}$ for 48 hours aiming to homogenize size and moisture of the samples.

The thermal treatments were carried out in a semi-continuous screw reactor that was development at the Laboratory of Panels and Wood Energy (LAPEM) linked to the Federal University of Viçosa (Minas Gerais, Brazil). The 2,3-meter-long equipment was built in carbon steel main structure with an indirect heating exchange system with a combustion gas followed by an indirect water coo ling system. The scheme of the reactor is presented in Figure 2.

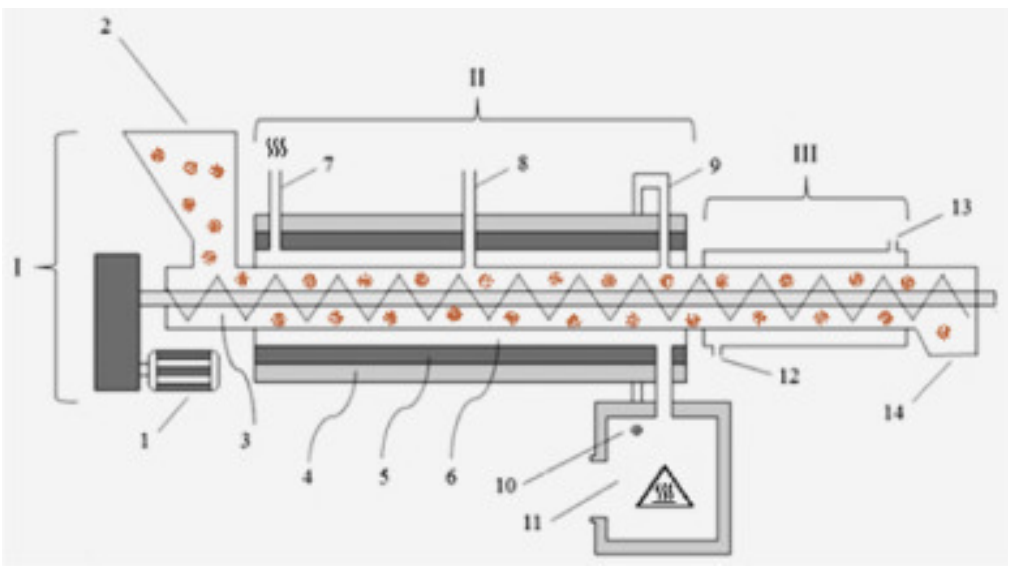

Figure 2: Lateral layout of a prototype screw reactor.

(Reprinted with permission from Da Silva et al. 2018. Copyright (2017) Elsevier B.V).

Legend: I - Transport System; II - Heating system; III - Cooling system; 1 - Motor; 2 - Input biomass; 3 - Worm-screw; 4 - Insulating layer; 5 - Refractory layer; 6 - Flow of heating gas; 7 - Heating gas output; 8 First "chimney"; 9 - Second "chimney"; 10 - Connection "chimney" with the burner; 11 - Connecting burner; 12 - Water supply; 13 - Water outlet; 14 - Exit of torrefied biomass.

The treatments were performed by gradually heating of samples along the 1,3-meter heating stage until reaching the final temperature of $\pm 300{ }^{\circ} \mathrm{C}$. Three residence times were evaluated at this stage $-3,9$, and 15 minutes - with the cooling being applied afterwards. Three samples were collected by treatments for their physicochemical characterization.

Moisture content, bulk density, and average size were determined with wood chips samples on a hygroscopic equilibrium condition at a controlled environment with a temperature of $\pm 20{ }^{\circ} \mathrm{C}$ and a humidity of $\pm 65 \%$. The analyses were carried out following the standards of DIN EN 14774-1-2010 and DIN EN 151032010. The approximate chemical composition (Volatile matter, Fixed carbon, and Ash), ultimate composition (Carbon, Oxygen and Hydrogen) and calorific value (Higher and Low Heating Value) were determined with milled and dried samples until reaching the absolutely dry mass. The analyses were carried out following the 
standards of ABNT NBR 8112-1983, DIN EN 15104-2011 and DIN EN 14918-2010, respectively.

The statistical analysis of data was carried out by equation adjust of linear and nonlinear models. In order to verify the significance of parameters of adjusted equation, Student's t-test was performed. The criterion used to determine the quality of the fit model to the experimental data was used the residual standard error (Sy.x) and coefficient adjusted of determination $\left(\mathrm{R}^{2}\right)$. The analyzes were performed using the $\mathrm{R}$ software.

\section{RESULTS AND DISCUSSION}

The Table 2 show the adjustments of the equations referring to the model that fitted better to the data dispersion. In general, it is observed that equations presented good adjustments for all proprieties analyzed.

Table 2: Model fit for the proprieties, significance of parameter estimative and precision measurements of equations.

\begin{tabular}{|c|c|c|c|c|c|c|}
\hline \multirow{2}{*}{ Ash (\%) } & \multirow{2}{*}{$\mathrm{Y}=\beta_{0}+\left(\beta_{1}{ }^{*} \mathrm{x}\right)$} & $\beta_{0}$ & 0,06 & 0,08 & \multirow{2}{*}{93,87} & \multirow{2}{*}{0,08} \\
\hline & & $\beta_{1}$ & 0,02 & $<0,001$ & & \\
\hline \multirow{2}{*}{ Carbon (\%) } & \multirow{2}{*}{$\mathrm{Y}=\beta_{0}+\left(\beta_{1} * \mathrm{x}\right)$} & $\beta_{0}$ & 46,99 & $<0,001$ & \multirow{2}{*}{95,91} & \multirow{2}{*}{1,06} \\
\hline & & $\beta_{1}$ & 0,99 & $<0,001$ & & \\
\hline \multirow{2}{*}{ Oxigen $(\%)$} & \multirow{2}{*}{$\mathrm{Y}=\beta_{0}+\left(\beta_{1}{ }^{*} \mathrm{x}\right)$} & $\beta_{0}$ & 46,79 & $<0,001$ & \multirow{2}{*}{94,23} & \multirow{2}{*}{1,12} \\
\hline & & $\beta_{1}$ & $-0,92$ & $<0,001$ & & \\
\hline \multirow{2}{*}{ Hydrogen (\%) } & \multirow{2}{*}{$Y=\beta 0+\left(\beta 1 * x^{\wedge} 2\right)$} & $\beta_{0}$ & 5,61 & $<0,001$ & \multirow{2}{*}{95,29} & \multirow{2}{*}{0,16} \\
\hline & & $\beta_{1}$ & $-0,004$ & $<0,001$ & & \\
\hline \multirow{2}{*}{$\begin{array}{l}\text { Equilibrium } \\
\text { Moisture } \\
\text { Content (\%) }\end{array}$} & \multirow{2}{*}{$\mathrm{Y}=\beta_{0}+\left(\beta_{1}{ }^{*} \mathrm{x}\right)$} & $\beta_{0}$ & 12,18 & $<0,001$ & \multirow{2}{*}{87,56} & \multirow{2}{*}{1,17} \\
\hline & & $\beta_{1}$ & $-0,52$ & $<0,001$ & & \\
\hline \multirow{2}{*}{$\begin{array}{l}\text { Average Size } \\
(\mathrm{mm})\end{array}$} & \multirow{2}{*}{$\mathrm{Y}=\beta_{0}+\left(\beta_{1} * \mathrm{x}\right)$} & $\beta_{0}$ & 16,01 & $<0,001$ & \multirow{2}{*}{99,79} & \multirow{2}{*}{0,27} \\
\hline & & $\beta_{1}$ & $-0,22$ & $<0,001$ & & \\
\hline \multirow{2}{*}{$\begin{array}{l}\text { High Heating } \\
\text { Value_dry } \\
(\mathrm{MJ} / \mathrm{kg})\end{array}$} & \multirow{2}{*}{$\mathrm{Y}=\beta_{0}+\left(\beta_{1} * x\right)$} & $\beta_{0}$ & 18,67 & $<0,001$ & \multirow{2}{*}{95,02} & \multirow{2}{*}{0,39} \\
\hline & & $\beta_{1}$ & 0,28 & $<0,001$ & & \\
\hline \multirow{2}{*}{$\begin{array}{l}\text { Low Heating } \\
\text { Value_dry } \\
(\mathrm{MJ} / \mathrm{kg})\end{array}$} & \multirow{2}{*}{$\mathrm{Y}=\beta_{0}+\left(\beta_{1} * x\right)$} & $\beta_{0}$ & 15,24 & $<0,001$ & \multirow{2}{*}{82,10} & \multirow{2}{*}{1,09} \\
\hline & & $\beta_{1}$ & 0,37 & $<0,001$ & & \\
\hline \multirow{3}{*}{$\begin{array}{l}\text { Bulk Density } \\
\quad\left(\mathrm{kg} / \mathrm{m}^{3}\right)\end{array}$} & \multirow{3}{*}{$\begin{array}{c}\mathrm{Y}= \\
\beta_{0}+\left(\beta_{1} * \mathrm{t}\right)+\left(\beta_{2} * \mathrm{x}^{\wedge} 2\right)\end{array}$} & $\beta_{0}$ & 159,25 & $<0,001$ & \multirow{3}{*}{84,93} & \\
\hline & & $\beta_{1}$ & 2,46 & $<0,001$ & & 5,38 \\
\hline & & $\beta_{2}$ & $-0,29$ & $<0,001$ & & \\
\hline & & $\beta_{0}$ & 2465,43 & $<0,001$ & & \\
\hline $\begin{array}{l}\text { Energy Density } \\
\left(\mathrm{Mj} / \mathrm{m}^{3}\right)\end{array}$ & $\begin{array}{c}Y= \\
\beta_{0}+\left(\beta_{1}^{*} x\right)+\left(\beta_{2} * t^{\wedge} 2\right)\end{array}$ & $\beta_{1}$ & 79,00 & $<0,001$ & 89,06 & 52,53 \\
\hline & & $\beta_{2}$ & $-3,96$ & $<0,001$ & & \\
\hline
\end{tabular}

Legend: $\mathrm{R}^{2}(\operatorname{adj})$ - adjusted coefficient determination; $\mathrm{S}_{\mathrm{y} \cdot \mathrm{x}}$ - estimative standard error.

Physicochemical characterization of torrefied wood samples is graphically presented in Figure 3 and Figure 4. In the first one, increases in the fixed carbon, elemental carbon and ash contents as a function of the torrefaction time are observed, while the volatile matter and elemental oxygen contents presented a reduction. The hydrogen content showed a polynomial tendency, with initial increase, stabilization and subsequent reduction. In the second figure, increases in calorific value and reductions in moisture content and average size are observed. Bulk and energetic densities, as well as hydrogen content, showed a polynomial tendency with significant reductions in the longest residence time. 

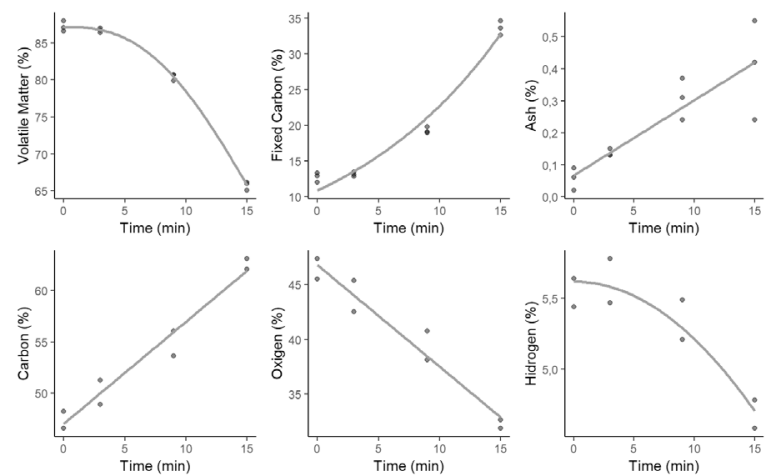

Figure 3: Approximated and ultimate chemical compositions of eucalyptus wood chips subjected to dry torrefaction until $300^{\circ} \mathrm{C}$ at a semi-continuous screw reactor.
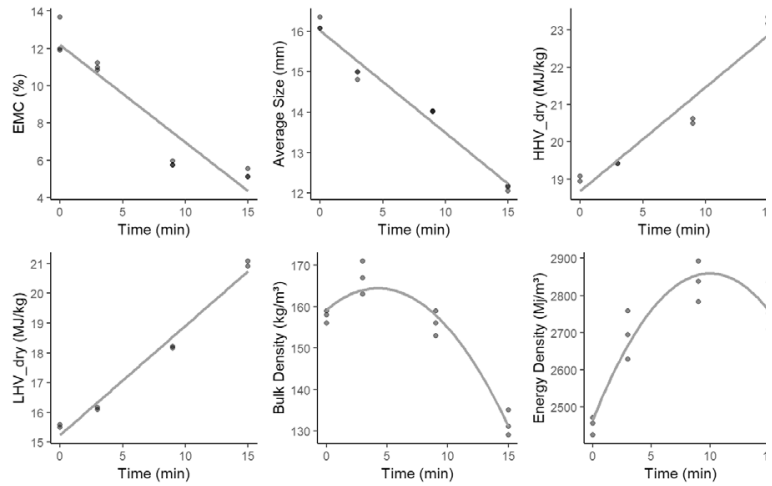

Figure 4: Physical and energetic properties of eucalyptus wood chips subjected to dry torrefaction until $300^{\circ} \mathrm{C}$ at a semi-continuous screw reactor. EMC: Equilibrium Moisture Content; HHV_dry: Higher Heating Value (dry); LHV_dry: Low Heating Value (dry).

Volatile matter is the organic structural fraction with the highest values of atomic $\mathrm{O} / \mathrm{C}$ ratio and the lowest thermal stability of the feedstock. Torrefaction is applied to promote a partial and selective degradation of this fraction of the biomass. There is a consequent increase of the remaining material contents, such as inorganics compounds and the lowest $\mathrm{O} / \mathrm{C}$ ratio organic compounds. These chemical changes explain the higher fixed carbon and ashes and the lower volatile matter of the torrefied biomass when compared to the raw material (Van der Stelt et al. 2011, Du et al. 2014).

The fraction of volatile matter has a lower calorific value than the fixed carbon fraction. Despite being easier to burn, the volatile matter generates moderate amounts of thermal energy during its combustion. Torrefied biomass presents a higher calorific value due to the increase in the fixed carbon ratio of its approximate chemical composition (Du et al. 2014). Ashes are considered inert materials during the combustion of biomass, do not contributing energetically to its calorific value (Pereira et al. 2013). However, the ashes presence in high contents can increase the costs of cleaning and maintain the burning equipment (Nunes et al. 2016).

The lower equilibrium moisture content at the torrefied biomass is caused by the reduction of its hygroscopicity through the thermal treatment (Acharjee et al. 2011). The torrefaction partially eliminates the hydrophilic groups present in the lignocellulosic structure, in particular through the partial degradation of the polysaccharide fraction. The moisture reduction is advantageous by increasing the efficiency and yields of all stages of processing and conversion of biomass into energy. The presence of high water contents in the fuel increases transport and storage costs and reduces the low heating value during the combustion (Swithenbank et al. 2011).

The biomass drying characterizes the first stage of torrefaction. At this stage, there is not a significant loss 
of dry mass, only the elimination of water contents with a consequent contraction of biomass. This reduction in volume without mass loss initially increases the bulk density of the biomass subjected to torrefaction. The significant increase in the mass loss occurs at the next stage with increasing torrefaction time and temperature. At this stage, the bulk density of the biomass tends to decrease due to the reduction of mass without significant changes in its volume. Lower values of density reduce the yields in the processing and conversion of biomass into energy (Hill et al. 2013).

\section{CONCLUSIONS}

Torrefaction promotes increases in the carbon, energy, and ashes contents of wood chips; and reductions of volatile matter content, equilibrium moisture, and average size; the bulk and energy densities exhibit an initial increase with a later reduction.

In general, torrefied wood chips have better indices of quality for the production of heat and energy than raw wood chips.

Woody biomass production, in particular from eucalyptus planted forest, can enable the development of a production chain of torrefied biomass in Brazil due the supplying of raw materials in high quantity and quality.

\section{ACKNOWLEDGMENTS}

The authors thank to: (I) The financial support of FAPEMIG (Fundação de Amparo à Pesquisa do Estado de Minas Gerais) and CAPES (Coordenação de Aperfeiçoamento de Pessoal de Nível Superior); (II) The technical support of Panels and Wood Energy Laboratory (LAPEM/DEF/UFV), in particular to Eder Cabral de Sousa.

\section{REFERENCES}

Acharjee, T.C.; Coronella, C.J.; Vasquez, V.R. 2011. Effect of thermal pretreatment on equilibrium moisture content of lignocellulosic biomass. Bioresource Technology 102: 4849-4854.

Acharya, B.; Dutta, A.; Minaret, J. 2015. Review on comparative study of dry and wet torrefaction. Sustainable Energy Technologies and Assessments 12: 26-37.

Almeida, G.; Brito, J.O.; Perré, P. 2010. Alterations in energy properties of eucalyptus wood and bark subjected to torrefaction: The potential of mass loss as a synthetic indicator. Bioresource Technology 101: 9778-9784.

Associação Brasileira de Normas Técnicas - ABNT -NBR. 1983. Carvão Vegetal - Análise Imediata. ABNT -NBR 8112. 1983. Rio de Janeiro: ABNT -NBR.

Bach, Q.V.; Skreiberg, Ø. 2016. Upgrading biomass fuels via wet torrefaction: A review and comparison with dry torrefaction. Renewable and Sustainable Energy Reviews 54: 665-677.

Da Silva, C.M.S.; Carneiro, A.C.O.; Pereira, B.L.C.; Vital, B.R.; Alves, I.C.N.; Magalhães, M.A. 2016. Stability to thermal degradation and chemical composition of woody biomass subjected to the torrefaction process. European Journal of Wood and Wood Products 4(6): 845-850.

Da Silva, C.M.S.; Carneiro, A.C.O.; Vital, B.R.; Figueiró, C.G.; Fialho, L.F.; Magalhães, M.A.; Carvalho, A.G.; Cândido, W.L. 2018. Biomass torrefaction for energy purposes - Definitions and an overview of challenges and opportunities in Brazil. Renewable and Sustainable Energy Reviews 82: 2426-2432.

Deutsches Institut Für Normung. DIN-EN. 2010. Determination of moisture content - Oven dry method - Part 1: Total moisture - Reference method. DIN-EN 14774-1. 2010. Berlim: CEN. 10p.

Deutsches Institut Für Normung. DIN-EN. 2010. Determination of calorific value. DIN - EN 14918. 2010. Belim: CEN, 2010. 63p.

Deutsches Institut Für Normung. DIN-EN. 2010. Determination of bulk density. DIN - EN 15103. 2010. Berlim: CEN. 14p. 
Deutsches Institut Für Normung. DIN-EN. 2011. Determination of total content of carbon, hydrogen and nitrogen - Instrumental methods. DIN-EN 15104. 2011. Berlim: CEN. 15p.

Du, S.; Chen, W.; Lucas, J.A. 2014. Pretreatment of biomass by torrefaction and carbonization for coal blend used in pulverized coal injection. Bioresource Technology 161 :333-339.

Esteves, B.M.; Pereira, H.M. 2009. Wood modification by heat treatment: a review. BioResources 4 (1): $370-404$.

Hill, S.J.; Grigsby, W.J.; Hall, P.W. 2013. Chemical and cellulose crystallite changes in Pinus radiata during torrefaction. Biomass and Bioenergy 56: 92-98.

Indústria Brasileira de Árvores - IBÁ. 2017. Report 2017. Brazil. 80p.

Koppejan, J.; Sokhansanj, S.; Melin, S.; Madrali, S. 2012. Status overview of torrefaction technologies. IEA Bioenergy Task 32 - Final Report. 54 p.

Medic, D.; Darr, M.; Shah, A.; Potter, B.; Zimmerman, J. 2012. Effects of torrefaction process parameters on biomass feedstock upgrading. Fuel 91: 147-154.

Nunes, L.J.R.; Matias, J.C.O.; Catalão, J.P.S. 2016. Biomass combustion systems: A review on the physical and chemical properties of the ashes. Renewable and Sustainable Energy Reviews 53: 235-242.

Parparita, E.; Brebu, M.; Uddin, M.A.; Yanik, Y.; Vasile, C. 2014. Pyrolysis behaviors of various biomasses. Polymer Degradation and Stability 100: 1-9.

Pereira, B.L.C.; Carneiro, A.C.O.; Carvalho, A.M.M.L.; Colodette, J.L.; Oliveira, A.C.; Fontes, M.P.F. 2013. Influence of Chemical Composition of Eucalyptus Wood on Gravimetric Yield and Charcoal Properties. BioResources 8(3): 4574-4592.

Pérez, L.E.A.; Segura, C.; Espinoza, D.; Radovic, L.R.; Jiménez, R. 2015. Torrefaction of Pinus radiata and Eucalyptus globulus: A combined experimental and modeling approach to process synthesis. Energy for Sustainable Development 29: 13-23.

Shen, D.K.; Gu, S.; Bridgwater, A.V. 2010. The thermal performance of the polysaccharides extracted from hardwood: Cellulose and hemicelluloses. Carbohydrate Polymers 82: 39-45.

Stape, J.L.; Binkley, D.; Ryan, M.G.; Fonseca, S.; Loss, R.A.; Takahashi, E.N.; Silva, C.R.; Hakamada, R.E.; Ferreira, J.M.A.; Lima, A.M.N.; Gava, J.L.; Leita, F.P.; Andrade, H.B.; Alves, J.M.; Silva, G.G.C.; Azevedo, M.R. 2010. The Brazil Eucalyptus Potential Productivity Project: Influence of water, nutrients and stand uniformity on wood production. Forest Ecology and Management 259: 1684-1694.

Swithenbank, J.; Chen, Q.; Zhang, X.; Sharifi, V.; Pourkashanian, M. 2011. Wood would burn. Biomass and Bioenergy 35(3): 999-1007.

Uslu, A.; Faaij, A.P.C.; Bergman, P.C.A. 2008. Pre-treatment technologies, and their effect on international bioenergy supply chain logistics. Techno-economic evaluation of torrefaction, fast pyrolysis and pelletisation. Energy 33(8): 1206-1223.

Van der Stelt, M.J.C.; Gerhauser, H.; Kiel, J.H.A.; Ptasinski, K.J. 2011. Biomass upgrading by torrefaction for the production of biofuels: A review. Biomass and Bioenergy 35: 3748-3762.

Vital, B.R.; Carneiro, A.C.O.; Pereira, B.L.C. 2013. Qualidade da madeira para fins energéticos. In: Santos, F.; Colodette, J.L.; Queiroz, J.H. (Eds.). Bioenergia \& Biorrefinaria - Cana-de-açúcar \& Espécies Florestais", Viçosa, MG. 271-298.

Wild, M.; Deutmeyer, M. 2016. Possible effects of torrefaction on biomass trade. IEA Bioenergy: Task 40. $68 \mathrm{p}$.

Yue, Y.; Singh, H.; Singh, B.; Mani, S. 2017. Torrefaction of sorghum biomass to improve fuel properties. Bioresource Technology 232: 372-379. 